\title{
Insulin stimulates glucose uptake via a phosphatidylinositide 3-kinase-linked signaling pathway in bovine mammary epithelial cells
}

\author{
K. Zhao, ${ }^{*} †$ H.-Y. Liu, ${ }^{, 1}$ M.-M. Zhou, ${ }^{*}$ F.-Q. Zhao, ${ }^{*} \ddagger$ and J.-X. Liu*1 \\ *Institute of Dairy Science, MOE Key Laboratory of Molecular Animal Nutrition, Zhejiang University, Hangzhou 310058, P. R. China \\ †Shaanxi Institute of Zoology, 88 Xingqing Road, X'an 710032, P. R. China \\ łLaboratory of Lactation and Metabolic Physiology, Department of Animal Science, University of Vermont, Burlington 05405
}

\begin{abstract}
The aim of this study was to investigate the effects of insulin on glucose uptake in lactating bovine mammary epithelial cells (BMEC). Primary BMEC were cultured in Dulbecco's modified Eagle's medium/nutrient mixture F-12 and treated with different levels of insulin (0, 5,50 , and $500 \mathrm{ng} / \mathrm{mL}$ ) for $48 \mathrm{~h}$ after a 24 -h starvation without fetal calf serum. Compared with the control cells (0 ng of insulin $/ \mathrm{mL}$ ), cell proliferation was enhanced by insulin treatment at all tested levels. Insulin significantly increased glucose uptake at a concentration of $500 \mathrm{ng} / \mathrm{mL}$. In addition, the protein synthesis inhibitor cycloheximide $(0.5 \mathrm{mg} / \mathrm{mL})$ counteracted the insulin-elevated glucose uptake, thereby suggesting that newly synthesized transporter protein might take part in the insulin-induced glucose uptake. Furthermore, pretreatment of the cells with SB203580, an inhibitor of p38 mitogen-activated protein kinase, did not influence the insulin-induced glucose uptake, but LY294002, a specific inhibitor of phosphatidylinositide 3-kinase, significantly reduced the insulin-stimulated glucose uptake. These results indicated that insulin-induced glucose uptake in BMEC may involve the phosphatidylinositide 3-kinase- but not mitogen-activated protein kinase-mediated signaling pathways.
\end{abstract}

Key words: bovine, insulin, glucose uptake, glucose transporter 8 (GLUT8), mammary epithelial cell

\section{INTRODUCTION}

In milk production, glucose is the main precursor for the synthesis of lactose, which plays an important role in controlling milk volume by maintenance of milk osmolarity. In dairy cows, glucose is essentially taken up by the mammary gland from the blood because the mammary gland cannot synthesize glucose due to its deficiency of glucose-6-phosphatase (Scott et al., 1976). Thus, glucose transport into the mammary gland is a

Received November 27, 2013

Accepted February 27, 2014.

${ }^{1}$ Corresponding authors: hyliu@zju.edu.cn and liujx@zju.edu.cn potential regulator of milk production. Insulin is a key metabolic hormone in the regulation of plasma glucose concentrations, and it stimulates glucose uptake in adipose tissue and striated muscle mainly via stimulation of the translocation of facilitative glucose transporter (GLUT) 4 from intracellular pools to the plasma membrane (Birnbaum, 1989; Gumà et al., 1995; Bryant et al., 2002). Because GLUT4 is not expressed in the lactating mammary gland of dairy cows (Zhao et al., 1996; Komatsu et al., 2005) and because the plasma insulin concentration decreases in lactating cows compared with their nonlactating counterparts (Peel et al., 1983; Rose et al., 1997), it is generally considered that glucose uptake in lactating bovine mammary epithelial cells (BMEC) may not be regulated by insulin. However, supplementation of insulin stimulates glucose uptake in mammary explants and epithelial cells (Moretti and DeOme, 1962; Myung and Ahn, 2002), and specific insulin receptors have been characterized in bovine mammary tissue (Oscar et al., 1986). Thus, it is possible that insulin may regulate glucose uptake in the bovine mammary gland. In this study, we showed that insulin stimulates mammary glucose uptake in BMEC and this stimulation is through a phosphatidylinositide 3-kinase (PI3-K)-dependent mechanism.

\section{MATERIALS AND METHODS}

\section{Cell Culture and Treatment}

Primary BMEC were isolated and cultured as described previously (Zhao et al., 2010; Liu et al., 2013). The cells used in this study were within passage 8, and the cells were from the mid-lactation stage. Unless otherwise stated below, the cells were seeded at a density of $5 \times 10^{4}$ cells $/ \mathrm{mL}$ in Dulbecco's modified Eagle's medium/nutrient mixture F-12 (DMEM/F12; Gibco Laboratories, Gaithersburg, MD) containing $10 \%$ fetal calf serum and $1 \%$ penicillin plus streptomycin (Sangong Co. Ltd., Shanghai, China) in 35-mm plates (Corning Inc., Corning, NY), and the cells were cultured at $37^{\circ} \mathrm{C}$ in an atmosphere of $5 \% \mathrm{CO}_{2}$. After $24 \mathrm{~h}$ of serum starvation, the cells were treated with 
different concentrations of insulin $(0,5,50$, and 500 $\mathrm{ng} / \mathrm{mL}$; Sigma, St. Louis, MO) for $48 \mathrm{~h}$ without fetal calf serum. Cells were then harvested to isolate RNA, which was stored at $-80^{\circ} \mathrm{C}$ until subsequent analysis. The culture medium was collected and immediately analyzed for glucose. To assess if ongoing protein synthesis was involved in the insulin-stimulated glucose uptake, BMEC were incubated with or without the protein synthesis inhibitor cycloheximide (CHX; 0.5 $\mu \mathrm{g} / \mathrm{mL}$; Sigma) for $48 \mathrm{~h}$. In additional experiments, the cells were pretreated with SB203580 [an inhibitor of mitogen-activated protein kinase (MAPK); 5, 10, 20, or $40 \mu M$; Sigma] or LY204002 (an inhibitor of PI3$\mathrm{K} ; 0.25,0.5,1$, or $2 \mu M$; Sigma) for $30 \mathrm{~min}$, which was followed by insulin treatment $(500 \mathrm{ng} / \mathrm{mL})$ for an additional $48 \mathrm{~h}$. The glucose uptake was analyzed as described below.

\section{Cell Proliferation}

Cell proliferation was measured by a 3-(4,5-dimethylthiazol-2-yl)-2,5-diphenyltetrazolium bromide (MTT) assay with a few modifications (Ip et al., 1992). Briefly, $2 \times 10^{4}$ cells/well were seeded in a 96-well plate. After incubation with different concentrations of insulin for $48 \mathrm{~h}$, the cells were incubated with the same medium containing $0.5 \mathrm{mg} / \mathrm{mL}$ of MTT (Sigma) at $37^{\circ} \mathrm{C}$ for $4 \mathrm{~h}$. The MTT medium was then removed, and the resulting formazan crystals in the cells were solubilized in 200 $\mu \mathrm{L}$ of 2-propanol containing $0.04 M$ hydrochloride. The absorbance of the solution was detected by a spectrophotometer (SpectraMax M5; Molecular Devices LLC, Sunnyvale, CA) at $570 \mathrm{~nm}$, and the absorbance was directly proportional to viable cell numbers.

\section{Glucose Uptake}

The amount of glucose uptake in BMEC was determined by the difference of glucose concentrations in the culture medium before and after incubation of the cells (Accorsi et al., 2005). Glucose levels in the medium were determined by an enzymatic coloring glucose oxidase/peroxidase assay method (Tiffany et al., 1972). The results were expressed as micrograms of glucose per microgram of protein for the cells on the plate, and the protein content was determined by the method of Bradford (1976).

\section{Statistical Analysis}

All data were analyzed by one-way ANOVA and Duncan's multiple range test using SAS software (version 9.0; SAS Institute Inc., Cary, NC); $P<0.05$ was considered as a significant difference. The cells were

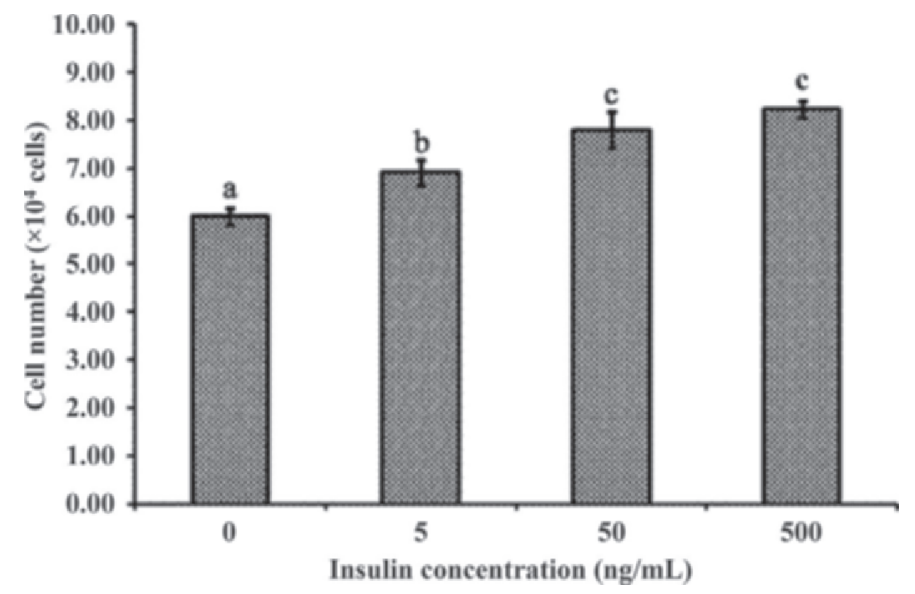

Figure 1. Cell proliferation of bovine mammary epithelial cells treated with different concentrations of insulin. Values with different letters $(\mathrm{a}-\mathrm{c})$ are significantly different $(P<0.05)$, and error bars indicate the SE $(\mathrm{n}=8)$.

isolated and pooled from 3 cows, and the experiments were repeated 3 times with at least 4 wells per treatment in each experiment.

\section{RESULTS}

\section{Effect of Insulin on Cell Proliferation}

Compared with the control cells ( $0 \mathrm{ng}$ of insulin/mL), supplementation of insulin at all concentrations (5, 50, and $500 \mathrm{ng} / \mathrm{mL}$ ) significantly stimulated cell proliferation $(P<0.05$; Figure 1$)$. However, cell proliferation was not further enhanced beyond $50 \mathrm{ng}$ of insulin $/ \mathrm{mL}$ $(P>0.05$; Figure 1$)$. These data indicate that insulin stimulates BMEC proliferation.

\section{Effect of Insulin on Glucose Uptake}

As shown in Figure 2, supplementation of insulin did not influence glucose uptake at concentrations of 5 and $50 \mathrm{ng} / \mathrm{mL}(P>0.05)$, but $500 \mathrm{ng}$ of insulin/ $\mathrm{mL}$ significantly enhanced the glucose uptake in BMEC $(P<0.05)$ compared with the control group $(0 \mathrm{ng}$ of insulin $/ \mathrm{mL}$ ). These data suggest that the treatment of BMEC with a high concentration of insulin above a certain threshold leads to a significant increase in glucose uptake.

\section{Effect of CHX on Insulin-Stimulated Glucose Uptake}

To study the involvement of protein synthesis in insulin-stimulated glucose uptake, BMEC were treated with CHX, a protein synthesis inhibitor, before insulin treatment. The effect of CHX on insulin-stimulated glucose uptake is shown in Figure 3. When the cells 


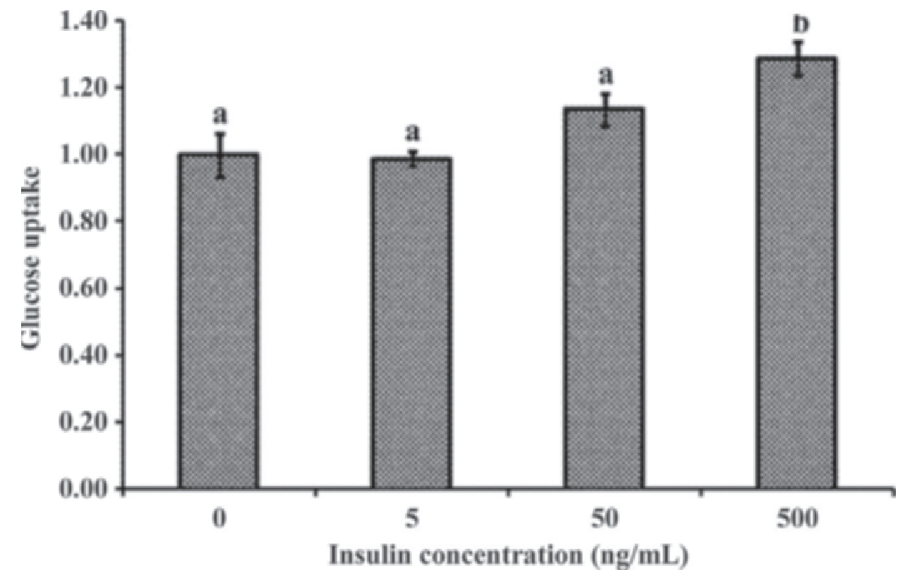

Figure 2. Glucose uptake of bovine mammary epithelial cells treated with different concentrations of insulin for $48 \mathrm{~h}$. The glucose uptake in insulin-treated cells is expressed relative to the glucose uptake in cells receiving no insulin, which is set to 1.0. Error bars indicate the $\mathrm{SE}(\mathrm{n}=6)$, and values with different letters ( $\mathrm{a}$ and $\mathrm{b})$ are significantly different $(P<0.05)$.

were treated with insulin $(500 \mathrm{ng} / \mathrm{mL})$ or CHX (0.5 $\mathrm{mg} / \mathrm{mL}$ ) alone, insulin significantly increased glucose uptake $(P<0.05)$ and CHX did not have an effect on glucose uptake compared with the control group (no insulin or CHX treatment). When the cells were treated with both CHX and insulin, the insulin-stimulated glucose uptake was completely abolished $(P<0.05)$. These results suggest that newly synthesized proteins are involved in the insulin-stimulated glucose uptake in BMEC.

\section{Effects of SB203580 and LY294002 on Insulin-Stimulated Glucose Uptake}

To study the involvement of p38 MAPK and PI3-K in insulin-stimulated glucose uptake, BMEC were treated with either SB203580 or LY294002, the specific inhibitors of MAPK and PI3-K, respectively, before insulin treatment. Pretreatment of BMEC with SB203580 (5, $10,20$, or $40 \mu M)$ had no effect on basal glucose uptake in BMEC at any of the tested concentrations (Figure 4A). Similarly, compared with the group supplemented with $500 \mathrm{ng}$ of insulin/mL alone, glucose uptake in insulin-treated cells was not affected by SB203580 treatment at concentrations of 20 or $40 \mu M(P>0.05$; Figure 4B). These results suggest that the p38 MAPK pathway may not be involved in the insulin-stimulated glucose uptake in BMEC.

Pretreatment of BMEC with LY294002 at concentrations of 0.25 and $0.5 \mu M$ did not affect the basal glucose uptake, but the higher concentrations of LY294002 (1 or $2 \mu M)$ significantly inhibited the basal glucose uptake $(P<0.05$; Figure 5A). The LY294002 treatment at con- centrations of 0.5 and $1 \mu M$ also significantly inhibited insulin-stimulated glucose uptake in a dose-dependent manner $(P<0.05$; Figure 5B). These observations indicate that the PI3-K pathway may be involved in the insulin-stimulated glucose uptake in BMEC.

\section{DISCUSSION}

Lactation in dairy cows requires a large supply of glucose to the mammary gland (Bell and Bauman, 1997). During late pregnancy and early lactation, the muscle and adipose tissues become less sensitive to insulin stimulation of GLUT4 translocation to the plasma membrane (Rose et al., 1997; Komatsu et al., 2005; Giesy et al., 2012). This insulin resistance, together with a decrease in plasma insulin concentration in early lactation (de Feu et al., 2009), is believed to mediate the priority of glucose supply from the peripheral tissues to the mammary gland because the glucose uptake in the lactating mammary gland is considered to be insulin-insensitive due to the absence of GLUT4 expression (Zhao et al., 1996; Komatsu et al., 2005). However, in the present study, we showed that supplementation of insulin $(500 \mathrm{ng} / \mathrm{mL})$ significantly increased glucose uptake in lactating BMEC. Our data provides a new line of evidence that glucose uptake in lactating bovine mammary gland may be regulated by insulin via a GLUT4-independent mechanism.

Insulin may stimulate glucose uptake in BMEC through upregulating GLUT8 expression. Our previous

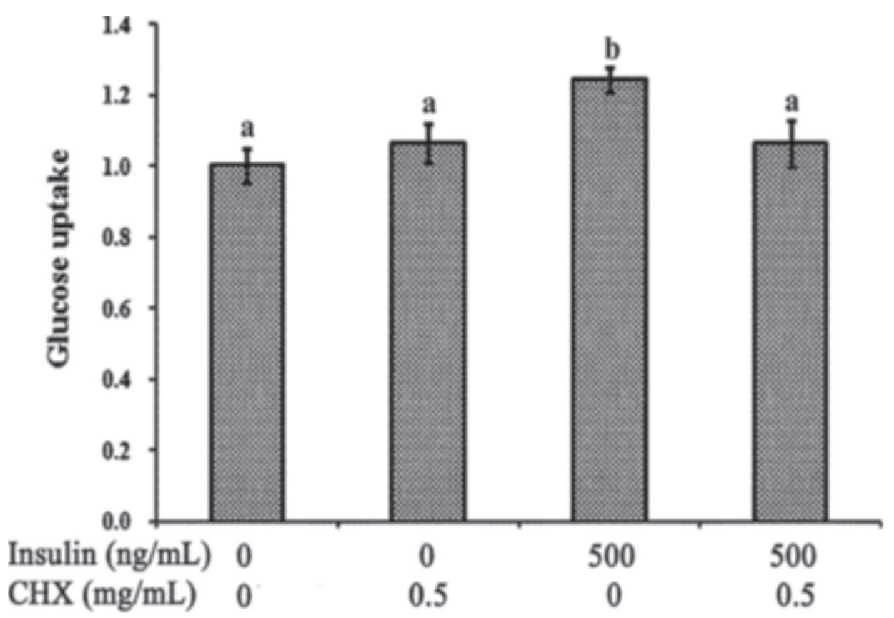

Figure 3. Effect of cycloheximide (CHX) on insulin-stimulated glucose uptake in bovine mammary epithelial cells. Cells were incubated in medium with or without insulin $(500 \mathrm{ng} / \mathrm{mL})$ in the absence or presence of CHX $(0.5 \mathrm{mg} / \mathrm{mL})$. The glucose uptake in each group is expressed as a value relative to that in cells without insulin or CHX treatment, which is set to 1.0. Values with different letters (a and b) are significantly different $(P<0.05)$, and error bars indicate the SE $(\mathrm{n}=6)$. 
$\mathbf{A}$

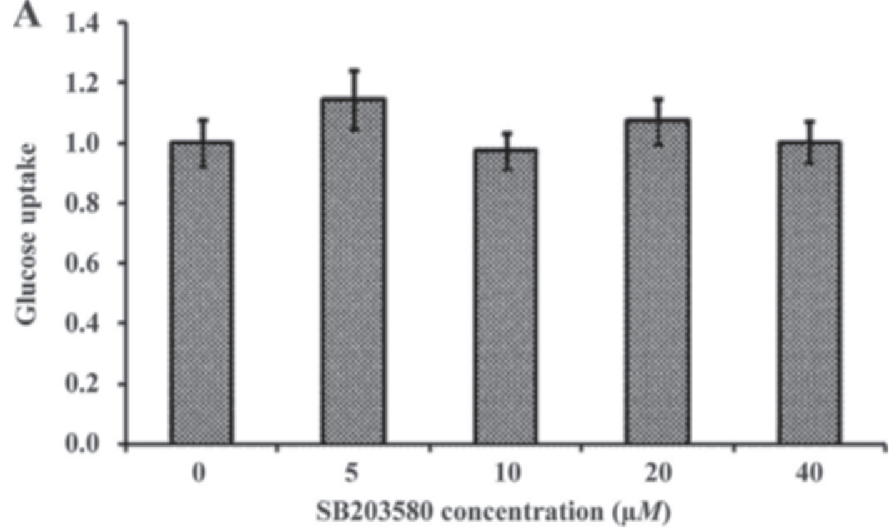

B

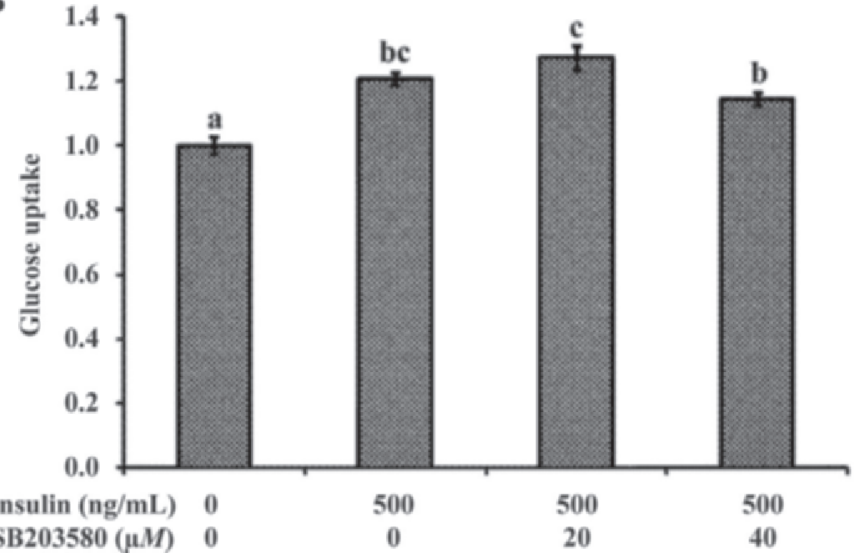

Figure 4. Effects of SB2030580, an inhibitor of mitogen-activated protein kinase, on insulin-stimulated glucose uptake in bovine mammary epithelial cells. The glucose uptake in individual groups is expressed as a value relative to that of the group without SB203580 (A) or SB203580 and insulin (B) treatment, which is set to 1.0. Values with different letters $(\mathrm{a}-\mathrm{c})$ are significantly different $(P<0.05)$, and error bars indicate the $\mathrm{SE}(\mathrm{n}=6)$.

study has shown that insulin increases GLUT8 expression in BMEC even at a low concentration of $5 \mathrm{ng} /$ $\mathrm{mL}$ (Zhao et al., 2012), which is in the physiological range of plasma insulin levels of lactating dairy cows (Blum et al., 1973). Glucose uptake in mammary epithelial cells is a facilitative process mediated by GLUT. Bovine mammary glands mainly express GLUT1 and GLUT8 (Zhao et al., 1996, 2004), and their expression levels increase by 100- and 10-fold, respectively, from late pregnancy to early lactation (Zhao and Keating, 2007). Because of the predominant expression and basal lateral membrane localization, GLUT1 is considered to be the major GLUT responsible for glucose uptake in mammary epithelial cells (Zhao, 2014), which is also supported by the observation that hypoxia increases GLUT1 expression and decreases GLUT8 expression but ultimately increases overall glucose uptake in BMEC (Zhao, 2014). Our previous study has shown that insulin does not affect the expression of GLUT1
A

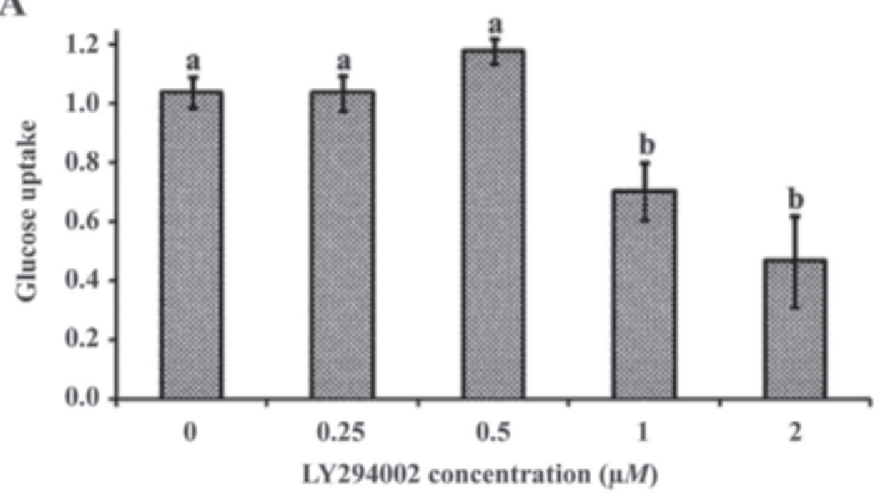

B

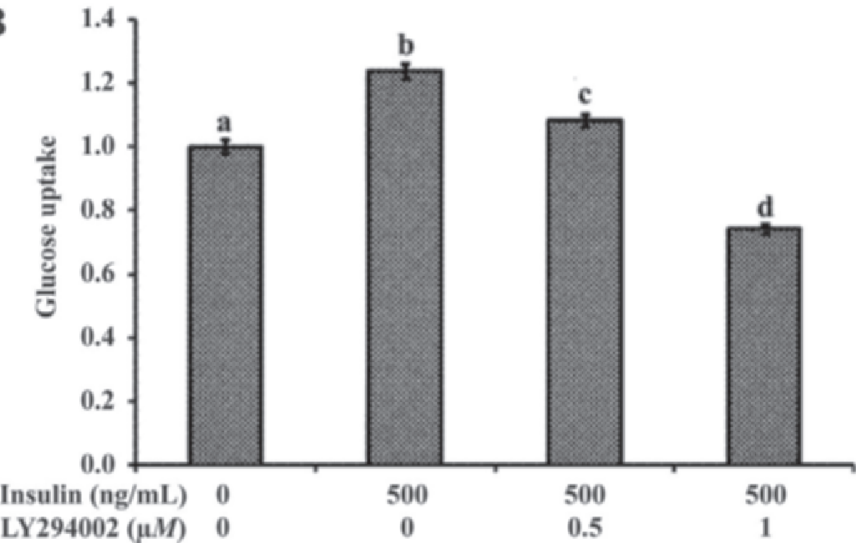

Figure 5. Effects of LY294002, an inhibitor of phosphatidylinositide 3-kinase, on insulin-stimulated glucose uptake in bovine mammary epithelial cells. The glucose uptake in individual groups is expressed as a value relative to that of the group without LY294002 (A) or LY294002 and insulin (B) treatment, which is set to 1.0. Values with different letters $(\mathrm{a}-\mathrm{d})$ are significantly different $(P<0.05)$, and error bars indicate the $\mathrm{SE}(\mathrm{n}=6)$.

in BMEC (Zhao et al., 2012), which is consistent with GLUT1 as an insulin-independent transporter (Pessin and Bell, 1992; Komatsu et al., 2005). Thus, although our study showed that insulin may stimulate GLUT8mediated glucose uptake in BMEC, this stimulation may not have a significant effect on overall glucose uptake in the mammary gland in supporting lactation.

However, this study also showed that insulin stimulated the proliferation of BMEC as in other cells, such as SH-SY5Y (Meghani et al., 1993), neuroretina (Hernández-Sánchez et al., 1995), and rat Schwann cells (Fex Svenningsen and Kanje, 1996). The growth of cells depends on energy and substrate supply. Glucose is the main calorie resource in mammalian cells (Liu et al., 2011). In addition, the intermediary metabolites of glucose, such as glucose-6-phosphate and NADPH, can act as survival factors of cells (Plas et al., 2002; Nutt et al., 2005). Therefore, insulin may stimulate GLUT8mediated glucose uptake to support the increased need for glucose in cell proliferation. 
To study whether insulin-induced glucose uptake in BMEC involved protein synthesis, insulin-stimulated glucose uptake was measured after incubating cells with CHX, which inhibits protein translation in mammalian cells at multiple steps with a particular potency on translation initiation (Obrig et al., 1971). Supplementation of cells with $0.5 \mathrm{mg}$ of $\mathrm{CHX} / \mathrm{mL}$, which did not affect the basal glucose uptake, completely suppressed the insulin-activated glucose uptake in BMEC. This result indicated that new synthesis of GLUT, rather than GLUT translocation, may be involved in the insulin-stimulated glucose uptake in BMEC. This observation was consistent with the report by Fladeby et al. (2003) who demonstrated that IGF-1-enhanced glucose uptake in chromaffin cells is dependent on the new synthesis of transporters. It is likely that insulin stimulates GLUT8 protein synthesis in BMEC, which accounts for the enhanced glucose uptake of the cells.

To further investigate the mechanism of insulin-stimulated glucose uptake in BMEC, the insulin signaling pathways were investigated. Phosphatidylinositide 3-kinase plays a central role in insulin signal transduction (Okada et al., 1994; Leibiger et al., 2010). Many studies have demonstrated that PI3-K is necessary for insulinstimulated GLUT4 translocation (Martin et al., 1996; Ono et al., 2001). In addition, although controversial, p38 MAPK may also be involved in the insulin-dependent glucose transport system (Somwar et al., 2000, 2002; Geiger et al., 2005). To study the involvement of PI3-K and p38 MAPK in insulin-stimulated glucose uptake in BMEC, we treated BMEC with SB203580 and LY294002, the specific inhibitors of MAPK and PI3-K, respectively, before treatment with insulin. Our results showed that LY294002 (0.5 and $1 \mu M)$, but not SB203580 (20 and $40 \mu M)$, significantly inhibited insulin-stimulated glucose uptake, thereby suggesting that insulin may stimulate glucose uptake through the PI3-K pathway, but not the p38 MAPK pathway, in BMEC. It is possible that insulin may activate PI3-Kdependent signaling pathways in BMEC to stimulate GLUT8 expression.

However, we cannot rule out the possibility that the glucose uptake stimulated by insulin in this study may not be mediated by GLUT8. First, due to the unavailability of the specific antibody against bovine GLUT8, we were unable to study GLUT8 protein expression and subcellular localization. It is not clear if GLUT8 is localized to the plasma membrane in BMEC, which is essential for glucose uptake. Second, in this study, GLUT8 expression was significantly increased by insulin at all concentrations examined (5, 50, and $500 \mathrm{ng} /$ $\mathrm{mL}$ ), but the insulin effect was not dose dependent. However, glucose uptake of the cells tended to be increased by insulin in a dose-dependent manner and was only significantly increased by insulin at $500 \mathrm{ng} / \mathrm{mL}$. Thus, increased GLUT8 expression did not necessarily result in enhanced glucose uptake, and the mRNA levels of GLUT8 might not be correlated with its protein levels. In addition, the results of this study were not consistent with the findings of Shao et al. (2013), who reported that the addition of $5 \mu \mathrm{g}$ of insulin/mL for 48 , 72 , or 96 h significantly increased mRNA expression of GLUT1, but not GLUT8 in bovine mammary explants. The inconsistency might be due to the complexity of cell populations in tissue explants, which may respond to insulin differently. Furthermore, because GLUT8 retains a dileucine motif similar to GLUT4 and may be located intracellularly in BMEC (Zhao et al., 2004), it is not known whether insulin is able to stimulate GLUT8 translocation in BMEC.

\section{CONCLUSIONS}

This study demonstrated that glucose uptake in lactating BMEC was responsive to insulin treatment. Insulin may stimulate glucose uptake in lactating BMEC by upregulating GLUT8 expression, and this stimulation may act through PI3-K-linked signaling pathways.

\section{ACKNOWLEDGMENTS}

This study was supported by the National Natural Science Foundation of China (Beijing, China; No. 30901034) and the earmarked fund for the China Agricultural Research System (CARS-37).

\section{REFERENCES}

Accorsi, P. A., M. Gamberoni, G. Isani, N. Govoni, R. Viggiani, M. Monari, M. De Ambrogi, A. Munno, C. Tamanini, and E. Seren. 2005. Leptin does not seem to influence glucose uptake by bovine mammary explants. J. Physiol. Pharmacol. 56:689-698.

Bell, A. W., and D. E. Bauman. 1997. Adaptations of glucose metabolism during pregnancy and lactation. J. Mammary Gland Biol. Neoplasia 2:265-278.

Birnbaum, M. J. 1989. Identification of a novel gene encoding an insulin-responsive glucose transporter protein. Cell 57:305-315.

Blum, J. W., R. B. Wilson, and D. S. Kronfeld. 1973. Plasma insulin concentrations in parturient cows. J. Dairy Sci. 56:459-464.

Bradford, M. M. 1976. A rapid and sensitive method for the quantitation of microgram quantities of protein dye binding. Anal. Biochem. 72:248-254.

Bryant, N. J., R. Govers, and D. E. James. 2002. Regulated transport of the glucose transporter GLUT4. Nat. Rev. Mol. Cell Biol. $3: 267-277$.

de Feu, M. A., A. C. O. Evans, P. Lonergan, and S. T. Butler. 2009. The effect of dry period duration and dietary energy density on milk production, bioenergetic status, and postpartum ovarian function in Holstein-Friesian dairy cows. J. Dairy Sci. 92:6011-6022.

Fex Svenningsen, A., and M. Kanje. 1996. Insulin and the insulin-like growth factors I and II are mitogenic to cultured rat sciatic nerve segments and stimulate ${ }^{[3 \mathrm{H}]}$ thymidine incorporation through their respective receptors. Glia 18:68-72.

Fladeby, C., R. Skar, and G. Serck-Hanssen. 2003. Distinct regulation of glucose transport and GLUT1/GLUT3 transporters by glucose 
deprivation and IGF-1 in chromaffin cells. Biochim. Biophys Acta 1593:201-208.

Geiger, P. C., D. C. Wright, D.-H. Han, and J. O. Holloszy. 2005. Activation of p38 MAP kinase enhances sensitivity of muscle glucose transport to insulin. Am. J. Physiol. Endocrinol. Metab. 288:E782-E788.

Giesy, S. L., B. Yoon, W. B. Currie, J. W. Kim, and Y. R. Boisclair. 2012. Adiponectin deficit during the precarious glucose economy of early lactation in dairy cows. Endocrinology 153:5834-5844.

Gumà, A., J. R. Zierath, H. Wallberg-Henriksson, and A. Klip. 1995. Insulin induces translocation of GLUT-4 glucose transporters in human skeletal muscle. Am. J. Physiol. 268:E613-E622.

Hernández-Sánchez, C., A. López-Carranza, C. Alarcón, E. J. de La Rosa, and F. de Pablo. 1995. Autocrine/paracrine role of insulinrelated growth factors in neurogenesis: Local expression and effects on cell proliferation and differentiation in retina. Proc. Natl. Acad. Sci. USA 92:834-9838.

Ip, M. M., S. F. Shoemaker, and K. M. Darcy. 1992. Regulation of rat mammary epithelial cell proliferation and differentiation by tumor necrosis factor- $\alpha$. Endocrinology 130:2833-2844.

Komatsu, T., F. Itoh, S. Kushibiki, and K. Hodate. 2005. Changes in gene expression of glucose transporters in lactating and nonlactating cows. J. Anim. Sci. 83:557-564.

Leibiger, B., T. Moede, S. Uhles, C. J. Barker, M. Creveaux, J. Domin, P.-O. Berggren, and I. B. Leibiger. 2010. Insulin-feedback via PI3K-C2 $\alpha$ activated $\mathrm{PKB} \alpha / \mathrm{Akt1}$ is required for glucose-stimulated insulin secretion. FASEB J. 24:1824-1837.

Liu, H., Q. Ma, and J. Li. 2011. High glucose promotes cell proliferation and enhances GDNF and RET expression in pancreatic cancer cells. Mol. Cell. Biochem. 347:95-101.

Liu, H., K. Zhao, and J. Liu. 2013. Effects of glucose availability on expression of the key genes involved in synthesis of milk fat, lactose and glucose metabolism in bovine mammary epithelial cells. PLoS ONE 8:e66092.

Martin, S. S., T. Haruta, A. J. Morris, A. Klippel, L. T. Williams, and J. M. Olefsky. 1996. Activated phosphatidylinositol 3-kinase is sufficient to mediate actin rearrangement and GLUT4 translocation in 3T3-L1 adipocytes. J. Biol. Chem. 271:17605-17608.

Meghani, M. A., D. M. Martin, J. R. Singleton, and E. L. Feldman. 1993. Effects of serum and insulin-like growth factors on human neuroblastoma cell growth. Regul. Pept. 48:217-224.

Moretti, R. L., and K. B. DeOme. 1962. Effect of insulin on glucose uptake by normal and neoplastic mouse mammary tissues in organ culture. J. Natl. Cancer Inst. 29:321-329.

Myung, K. H., and B. J. Ahn. 2002. Effects of gut extract protein and insulin on glucose uptake and GLUT 1 expression in HC 11 mouse mammary epithelial cells. Asian-australas. J. Anim. Sci. 15:1210-1214.

Nutt, L. K., S. S. Margolis, M. Jensen, C. E. Herman, W. G. Dunphy, J. C. Rathmell, and S. Kornbluth. 2005. Metabolic regulation of oocyte cell death through the CaMKII-mediated phosphorylation of caspase-2. Cell 123:89-103.

Obrig, T. G., W. J. Culp, W. L. McKeehan, and B. Hardesty. 1971. The mechanism by which cycloheximide and related glutarimide antibiotics inhibit peptide synthesis on reticulocyte ribosomes. J. Biol. Chem. 246:174-181.

Okada, T., Y. Kawano, R. Sakakibara, O. Hazeki, and M. Ui. 1994. Essential role of phosphatidylinositol 3-kinase in insulin-induced glucose transport and antilipolysis in rat adipocytes. Studies with a selective inhibitor wortmannin. J. Biol. Chem. 269:3568-3573.

Ono, H., H. Katagiri, M. Funaki, M. Anai, K. Inukai, Y. Fukushima, H. Sakoda, T. Ogihara, Y. Onishi, M. Fujishiro, M. Kikuchi, Y.
Oka, and T. Asano. 2001. Regulation of phosphoinositide metabolism, Akt phosphorylation, and glucose transport by PTEN (phosphatase and tensin homolog deleted on chromosome 10) in 3T3-L1 adipocytes. Mol. Endocrinol. 15:1411-1422.

Oscar, T. P., C. R. Baumrucker, and T. D. Etherton. 1986. Insulin binding to bovine mammary membranes: Comparison of microsomes versus smooth membranes. J. Anim. Sci. 62:179-186.

Peel, C. J., T. J. Fronk, D. E. Bauman, and R. C. Gorewit. 1983. Effect of exogenous growth hormone in early and late lactation on lactational performance of dairy cows. J. Dairy Sci. 66:776-782.

Pessin, J. E., and G. I. Bell. 1992. Mammalian facilitative glucose transporter family: Structure and molecular regulation. Annu. Rev. Physiol. 54:911-930.

Plas, D. R., J. C. Rathmell, and C. B. Thompson. 2002. Homeostatic control of lymphocyte survival: Potential origins and implications. Nat. Immunol. 3:515-521.

Rose, M. T., Y. Obara, F. Itoh, H. Hashimoto, and Y. Takahashi. 1997. Non-insulin- and insulin-mediated glucose uptake in dairy cows. J. Dairy Res. 64:341-353.

Scott, R. A., D. E. Bauman, and J. H. Clark. 1976. Cellular gluconeogenesis by lactating bovine mammary tissue. J. Dairy Sci. 59:50-56.

Shao, Y., E. H. Wall, T. B. McFadden, Y. Misra, X. Qian, R. Blauwiekel, D. Kerr, and F.-Q. Zhao. 2013. Lactogenic hormones stimulate expression of lipogenic genes but not glucose transporters in bovine mammary gland. Domest. Anim. Endocrinol. 44:57-69.

Somwar, R., S. Koterski, G. Sweeney, R. Sciotti, S. Djuric, C. Berg, J. Trevillyan, P. E. Scherer, C. M. Rondinone, and A. Klip. 2002. A dominant-negative p38 MAPK mutant and novel selective inhibitors of p38 MAPK reduce insulin-stimulated glucose uptake in 3T3-L1 adipocytes without affecting GLUT4 translocation. J. Biol. Chem. 277:50386-50395.

Somwar, R., M. Perreault, S. Kapur, C. Taha, G. Sweeney, T. Ramlal, D. Y. Kim, J. Keen, C. H. Cote, A. Klip, and A. Marette. 2000. Activation of p38 mitogen-activated protein kinase $\alpha$ and $\beta$ by insulin and contraction in rat skeletal muscle: Potential role in the stimulation of glucose transport. Diabetes 49:1794-1800.

Tiffany, T. O., J. M. Jansen, C. A. Burtis, J. B. Overton, and C. D. Scott. 1972. Enzymatic kinetic rate and end-point analyses of substrate, by use of a GeMSAEC fast analyzer. Clin. Chem. $18: 829-840$

Zhao, F.-Q. 2014. Biology of glucose transport in the mammary gland. J. Mammary Gland Biol. Neoplasia 19:3-17. http://dx.doi. org/10.1007/s10911-013-9310-8.

Zhao, F.-Q., W. T. Dixon, and J. J. Kennelly. 1996. Localization and gene expression of glucose transporters in bovine mammary gland. Comp. Biochem. Physiol. B Biochem. Mol. Biol. 115:127-134.

Zhao, F.-Q., and A. F. Keating. 2007. Expression and regulation of glucose transporters in the bovine mammary gland. J. Dairy Sci. 90(E. Suppl.):E76-E86.

Zhao, F.-Q., P. J. Miller, E. H. Wall, Y.-C. Zheng, B. Dong, M. C. Neville, and T. B. McFadden. 2004. Bovine glucose transporter GLUT8: Cloning, expression, and developmental regulation in mammary gland. Biochim. Biophys. Acta 1680:103-113.

Zhao, K., H.-Y. Liu, M.-M. Zhou, and J.-X. Liu. 2010. Establishment and characterization of a lactating bovine mammary epithelial cell model for the study of milk synthesis. Cell Biol. Int. 34:717-721.

Zhao, K., H.-Y. Liu, M.-M. Zhou, and J.-X. Liu. 2012. Lactogenic hormones regulation of glucose transporters gene expression in lactating bovine mammary epithelial cells. Asian J. Chem. 24:626-630. 